\title{
Ik denk dus ik leer?
}

Citation for published version (APA):

van Heugten, C. M. (2012). Ik denk dus ik leer? Maastricht University. https://doi.org/10.26481/spe.20120914ch

Document status and date:

Published: 14/09/2012

DOI:

10.26481/spe.20120914ch

Document Version:

Publisher's PDF, also known as Version of record

\section{Please check the document version of this publication:}

- A submitted manuscript is the version of the article upon submission and before peer-review. There can be important differences between the submitted version and the official published version of record.

People interested in the research are advised to contact the author for the final version of the publication, or visit the DOI to the publisher's website.

- The final author version and the galley proof are versions of the publication after peer review.

- The final published version features the final layout of the paper including the volume, issue and page numbers.

Link to publication

\footnotetext{
General rights rights.

- You may freely distribute the URL identifying the publication in the public portal. please follow below link for the End User Agreement:

www.umlib.nl/taverne-license

Take down policy

If you believe that this document breaches copyright please contact us at:

repository@maastrichtuniversity.nl

providing details and we will investigate your claim.
}

Copyright and moral rights for the publications made accessible in the public portal are retained by the authors and/or other copyright owners and it is a condition of accessing publications that users recognise and abide by the legal requirements associated with these

- Users may download and print one copy of any publication from the public portal for the purpose of private study or research.

- You may not further distribute the material or use it for any profit-making activity or commercial gain

If the publication is distributed under the terms of Article $25 \mathrm{fa}$ of the Dutch Copyright Act, indicated by the "Taverne" license above, 


\section{Maastricht University}

\section{Prof.dr. Caroline M. van Heugten}

Faculty of Health, Medicine and Life Sciences Faculty of Psychology and Neuroscience

\section{Ik denk dus ik leer?}


Ik denk dus ik leer? 


\section{Colofon}

Design \& print: Océ Business Services, Maastricht

ISBN: 978-90-5681-396-3

NUR: 870

Alle rechten voorbehouden. Niets uit deze uitgave mag worden verveelvoudigd, opgeslagen in een geautomatiseerd gegevensbestand of openbaar gemaakt worden, zonder voorafgaande schriftelijke toestemming van de auteur of uitgever. 


\section{Ik denk dus ik leer?}

Inaugurele rede uitgesproken ter aanvaarding van de

bijzondere leerstoel Klinische Neuropsychologie, in het bijzonder de Neuropsychologische Interventies.

Faculty of Health, Medicine and Life Sciences Faculty of Psychology and Neuroscience

Maastricht, 14 september 2012

Prof.dr. Caroline M. van Heugten 
Ik denk dus ik leer? 


\section{Ik denk dus ik leer?}

\section{Prof.dr. Caroline M. van Heugten}

Mijnheer de Rector Magnificus, gewaardeerde collega's, lieve familie en vrienden en andere toehoorders,

\section{Inleiding}

"Als ik mij ervan overtuigd heb dat er absoluut niets bestaat in de wereld, besta ik dan ook niet?" Deze vraag stelde René Descartes zichzelf om vervolgens ook zelf te antwoorden met de inmiddels zeer bekende uitspraak "Ik denk dus ik besta" waarmee hij de eerste waarheid had gevonden die de test van de methodische twijfel doorstond. Deze rede is getiteld “ik denk dus ik leer?" Deze vraag is relevant voor het onderzoek dat ik vanuit mijn leeropdracht zal uitvoeren en ik hoop $u$ in de komende 3 kwartier aan de hand te kunnen nemen op weg naar een mogelijk antwoord op deze vraag, als dat er al is.

Vandaag aanvaard ik mijn ambt als bijzonder hoogleraar in de Klinische Neuropsychologie, in het bijzonder de Neuropsychologische Interventies. Een hele mond vol, maar aan mij de uitdaging en de eer om u daarover van alles te leren. Een inaugurele rede is immers een openbare les en $u$ denkt dus u leert?

De klinische neuropsychologie is het wetenschapsgebied waarin de relatie tussen hersenstoornissen en gedrag bestudeerd wordt in patiëntgebonden onderzoek? Klinische neuropsychologie is ook een gezondheidszorggebied waarin de wetenschappelijke kennis wordt toegepast in de vorm van diagnostiek, begeleiding en behandeling van patiënten. Het is een deelgebied van de neuropsychologie dat zich in algemene zin bezighoudt met de relatie tussen hersenen en gedrag, zowel bij mensen als bij dieren en zowel bij gezonde als bij patiëntpopulaties.

Hersenstoornissen kunnen door allerlei oorzaken ontstaan waarbij ik mij in deze rede zal beperken tot vormen van verworven hersenletsel. Bij verworven hersenletsel is er schade aan de hersenen opgetreden na de geboorte (niet-aangeboren hersenletsel) en die schade leidt voor de getroffene veelal tot een onomkeerbare breuk in de levenslijn. Deze hersenbeschadiging kan door allerlei oorzaken ontstaan, zoals 
een cerebrovasculair accident (CVA) ofwel beroerte in de vorm van een hersenbloeding of herseninfarct, door letsel aan het hoofd van buitenaf zodat een traumatisch hersenletsel ontstaat, door ruimte-innemende processen (tumoren), infecties (hersenvliesontsteking) of andere ziekten waardoor degeneratie van het hersenweefsel optreedt (bijvoorbeeld bij multipele sclerose of de ziekte van Parkinson). Een hersenletsel kan zeer plotseling ontstaan zoals blijkt uit de eerste zinnen van het boek 'Het Ravijn' van journalist Max Pam²; een boek waarin hij verslag doet van zijn fysieke herstel na een beroerte, maar ook van de angsten die hij heeft ervaren als er iets mis gaat in je hoofd:

"Ik wilde mijn hand naar het hoofdje van mijn zoon uitstrekken, maar ik merkte tot mijn verrassing dat die handeling moeite kostte. Het leek wel of er een gewicht aan mijn arm hing. Voorzichtig probeerde ik overeind te komen, maar ook dat ging moeilijk. Pijn voelde ik niet. Het leek juist of mijn bewustzijn op een eigenaardige manier scherper was. Met onhandige roeibewegingen manoeuvreerde ik mij naar de rand van het bed en probeerde op te staan...."

Ook bij degeneratieve aandoeningen, zoals de ziekte MS, kan de ziekte je overvallen zoals blijkt uit een interview met Job Cohen over de ziekte van zijn vrouw:

"Ze zat te typen, en merkte opeens dat ze naast de toetsen sloeg. Haar hand deed het niet meer. Ik dacht direct aan iets ergs, was ontzettend bang dat er iets in haar hersenen zat. Lidie bedacht toen zelf: zou het geen MS kunnen zijn? Kort daarna is de diagnose gesteld."

In Nederland krijgen jaarlijks naar schatting 130.000 (nieuwe) mensen te maken met een vorm van niet aangeboren hersenletsel; het aantal mensen dat met de gevolgen van een hersenletsel leeft, is vele malen groter $^{3}$. Elke dag krijgen meer dan 100 mensen in ons land een beroerte 4 . Dat zijn schokkende aantallen die helaas naar verwachting de komende jaren nog verder gaan stijgen als gevolg van de vergrijzing, maar ook als gevolg van verbeterde medische zorg in het acute stadium direct na het optreden van het letsel5.

\section{Gevolgen van hersenletsel}

De directe gevolgen van hersenletsel kunnen steeds beter behandeld worden waardoor grotere aantallen mensen een hersenletsel overleven. 
Dat is natuurlijk heel goed nieuws, maar de andere kant van de medaille is dat er steeds meer mensen leven met de gevolgen van een hersenletsel, want bijna elk hersenletsel leidt tot - veelal blijvende restverschijnselen van zeer uiteenlopende aard en ernst. Dat betekent dat er meer behoefte aan langdurende zorg na hersenletsel zal zijn, maar helaas is de huidige gezondheidszorg daar nog niet voldoende op ingericht of voorbereid 6 .

Naast duidelijk zichtbare lichamelijke gevolgen zoals een halfzijdige verlamming, kan hersenletsel tot allerlei niet-lichamelijke gevolgen leiden die voor de buitenwereld niet of nauwelijks zichtbaar zijn. Dit zijn de neuropsychologische gevolgen en kunnen worden ingedeeld in de volgende 3 categorieën: cognitieve stoornissen of stoornissen in het denken, zoals geheugenstoornissen of een verminderde denksnelheid; emotionele gevolgen zoals somberheid of angst; en gedragsmatige gevolgen zoals agressie (te veel gedrag) of apathie (te weinig gedrag). Daarnaast is vermoeidheid een veel gehoorde klacht na hersenletsel en geven patiënten aan minder belastbaar te zijn. Dergelijke klachten kunnen lieden tot een cascade van problemen met overbelasting van zowel de patiënt als diens naastbetrokkenen tot gevolg. Het zijn vooral deze onzichtbare gevolgen die het dagelijks leven van de getroffenen negatief beïnvloeden, vooral bij patiënten die na opname in het ziekenhuis, revalidatiecentrum of verpleeghuis thuis in hun eigen omgeving de draad weer proberen op te pakken.

Doordat de neuropsychologische gevolgen aan de buitenkant minder zichtbaar zijn, wordt de aanwezigheid ervan veelal onderschat en wordt de ernst ervan vaak niet erkend of herkend. Dat geldt helaas niet alleen voor de patiënt en diens familie, maar ook nog steeds voor veel professionals in de gezondheidszorg. Uit onderzoek is gebleken dat in de eerste maand na een beroerte $60 \%$ van de patiënten langzamer - mentaal trager - is geworden op objectieve en gestandaardiseerde testen waarbij een bepaalde hoeveelheid cognitieve taken in korte tijd moet worden uitgevoerd. Als deze patiënten worden gevolgd blijkt dat er na 2 jaar nog steeds zo'n 40\% onder de norm scoort en dus langzamer is geworden ${ }^{7,8}$. Als ongeveer een jaar na de beroerte aan de patiënten zelf gevraagd wordt welke klachten zij ervaren, zegt 56\% langzamer te zijn geworden in het denken ${ }^{9}$. Als aan de partners gevraagd wordt welke klachten hun naaste sinds de beroerte ondervindt, blijkt dat de partners meer en andere problemen rapporteren 9 . $U$ kunt zich 
voorstellen dat als er bij beide partners geen overeenstemming over zulke ingrijpende gevolgen bestaat, dit tot desastreuze gevolgen in de thuissituatie kan leiden. Uit onderzoek bij patiënten die na een periode van revalidatie terug naar huis werden ontslagen, bleek zo'n $70 \%$ vermoeidheidsklachten te hebben ${ }^{10}$ en bleek $40 \%$ van de patiënten en zelfs $60 \%$ van hun partners na een jaar somber te zijn ${ }^{11,12}$. De helft van de onderzochte partners gaf zowel na 1 jaar als na 3 jaar aan ontevreden te zijn over de wijze waarop zij hun vrije tijd kunnen besteden ${ }^{12}$.

Ik hoef $u$ na deze inleiding vast niet meer te overtuigen van het belang van goede en effectieve behandeling voor deze problematiek en dat is nu precies de kern van mijn leeropdracht.

\section{Neuropsychologische behandeling: een referentiekader}

Om neuropsychologische behandeling en het wetenschappelijk onderzoek dat ik daarnaar uitvoer te kunnen toelichten, wil ik u graag een hulpmiddel aanreiken dat door de Wereldgezondheidsorganisatie is ontwikkeld om de gevolgen van een ziekte of aandoening in kaart te kunnen brengen, een soort kapstok. Dit referentiekader is de International Classification of Functioning, Disabilites and Health'3 ${ }^{13}$, kortweg ICF model genoemd.

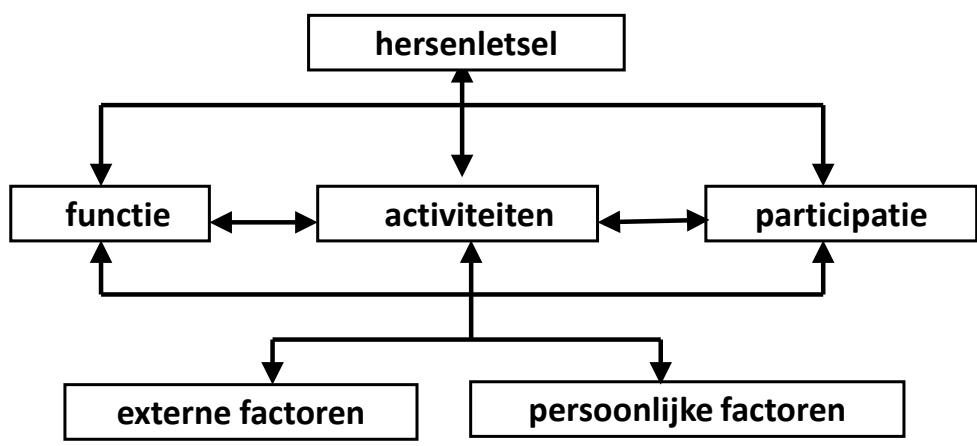

ICF model (WHO, 2002)

Het uitgangspunt is dat een persoon een ziekte of aandoening heeft die tot gevolgen kan leiden op 3 gebieden van het menselijk functioneren. Ten eerste kan er een verminderde functie of afwijkende structuur ontstaan als gevolg van de ziekte. Ten tweede kan de persoon in kwestie 
problemen ervaren bij het uitvoeren van activiteiten in het dagelijks leven. Ten derde kan er sprake zijn van een handicap of verminderde maatschappelijke participatie. In hoeverre de ziekte of aandoening invloed heeft op deze niveaus van functioneren, is voor ieder individu anders en wordt mede bepaald door persoonlijke factoren en externe factoren.

Ik zal het ICF model illustreren aan de hand van een voor de meesten van $u$ bekende patiënt. Het betreft een relatief jonge vrouw die een oogaandoening heeft, genaamd juveniele macula degeneratie. Als gevolg daarvan ziet zij met haar linkeroog $12 \%$ en met haar rechteroog $10 \%$. Het verminderde gezichtsvermogen beperkt haar bij het uitvoeren van dagelijkse activiteiten waarbij kleine letters moeten worden gelezen en dat is in heel veel situaties het geval: het gebruik van een mobiele telefoon, het opladen van een OV-chipkaart, het lezen van prijskaartjes en maten bij het kopen van kleding, het lezen van de bordjes bij de slager; het is teveel om op te noemen. Daarnaast kan zij geen autorijden en daarmee is haar mobiliteit beperkt, terwijl bovendien de meeste busstations voor slechtzienden niet meer toegankelijk zijn door de wijze waarop ze tegenwoordig zijn ingericht. Ondanks de vele beperkingen participeert zij in de maatschappij op hoog niveau; zo is zij onlangs benoemd tot professor en reist zij met haar echtgenoot zo'n beetje de hele wereld rond. Niet elke patiënt met deze geringe hoeveelheid gezichtsvermogen bereikt dezelfde mate van maatschappelijke participatie. Dat wordt vooral bepaald door de persoonlijke en omgevingsfactoren. Wat betreft de persoonlijke factoren: we hebben het hier over een slimme vrouw, optimistisch van aard en een echte doorzetter, zo eentje die niet bij de pakken neer gaat zitten maar elk probleem als een uitdaging oppakt. Wat betreft de externe factoren: zij heeft de beschikking over allerlei handige hulpmiddelen die deels door de zorgverzekeraar worden vergoed. En tot slot heeft zij een sterk sociaal netwerk dat haar op allerlei manieren steunt, zowel in praktische als in emotionele zin. Deze factoren geven haar veel mogelijkheden in het leven, maar maken het tegelijkertijd ook kwetsbaar. Zo is haar gezichtsvermogen de laatste 25 jaar stabiel slecht, maar de beperkingen die zij ondervindt nemen toe doordat de wereld om haar heen verandert. Steeds meer dagelijkse activiteiten worden uitgevoerd met gebruik van technologische toepassingen en helaas zijn die per definitie klein en worden steeds kleiner naarmate de ontwikkelingen vorderen. Vroeger kocht zij bijvoorbeeld een kaartje bij het stationsloket en was volledig zelfstandig; nu moet zij een 
beroep doen op haar hulpmiddelen of de hulp van anderen omdat de kaartjesautomaat niet is aangepast voor mensen met een verminderd gezichtsvermogen. Er zijn wel technologische toepassingen die geschikt zijn voor gebruik door slechtzienden, maar de makers daarvan denken dat een slechtziende ook minder slim is waardoor de hoeveelheid functies vaak dramatisch klein is.

Patiënten met hersenletsel moeten op dezelfde wijze hun weg zien te vinden in een complexe en dynamische maatschappij. Op functieniveau zijn het vooral de cognitieve, emotionele en gedragsmatige gevolgen die succesvolle maatschappelijke participatie van deze kwetsbare groep danig in de weg kunnen staan. Maar, net als bij de voorbeeldpatiënt, spelen persoonlijke en omgevingsfactoren een grote rol bij de maatschappelijke re-integratie na een hersenletsel.

\section{Revalideren is leren}

$\mathrm{Na}$ een hersenletsel kunnen er op alle gebieden van het menselijk functioneren problemen ontstaan en het zou natuurlijk het beste zijn als deze restverschijnselen spontaan zouden herstellen, maar dat is helaas bij veel hersenletselpatiënten niet het geval. Dat betekent dar er gerichte behandeling noodzakelijk is.

De neuropsycholoog, maar ook de andere betrokken zorgverleners, kan elk niveau van het ICF model als aangrijpingspunt voor behandeling kiezen. Er zijn wat mij betreft 4 centrale uitgangspunten bij de neuropsychologische behandeling:

- revalideren is leren;

- elke patiënt doorloopt zijn eigen, unieke leerproces;

- het doel van revalidatie is optimale participatie in de maatschappij;

- niet de werking van het brein staat centraal, maar het brein van de patiënt in maatschappelijk perspectief.

Dat revalideren leren is wordt duidelijk als we opnieuw kijken naar de ervaringen van mensen die een hersenletsel hebben overleefd, waarna een periode van revalidatie volgde:

Max Pam zegt: "in het Ravijn beschrijf ik hoe ik weer leerde lopen, veters strikken, fietsen en hoe ik mijn rijbewijs opnieuw moest halen."

De vrouw van Edwin van der Sar, Annemarie, zegt: "Ineens kun je de gewoonste handelingen niet meer automatisch doen. Ik moest van alles opnieuw leren. Lopen, iets pakken, zorgen voor je gezin, functioneren 
in drukke omgevingen, keuzes maken in winkels, zomaar een paar voorbeelden waar je dan tegenaan loopt."

Bij de behandeling na hersenletsel helpt de neuropsycholoog de patiënt om:

- oude vaardigheden opnieuw te leren;

- nieuwe vaardigheden aan te leren;

- de patiënt te leren omgaan met blijvende beperkingen;

- de patiënt en diens naasten te leren aanpassen aan een veranderd leven;

- en de patiënt en diens naasten het veranderde leven te leren accepteren.

Leren staat dus centraal. Maar wat is leren eigenlijk? Het woordenboek zegt: 'het verwerven van mogelijkheden tot (meer, ander) gedrag en handelingen door middel van het opdoen van ervaringen' (www.woorden-boek.nl), maar als ik aan u vraag wat u denkt dat leren is, krijg ik vast evenveel omschrijvingen als dat er mensen in deze zaal aanwezig zijn. Leren is heel vanzelfsprekend in ons dagelijks leven, maar helaas wordt er in relatie tot revalidatie en hersenletsel nog maar weinig onderzoek naar gedaan. Een belangrijke vraag voor mij als neuropsycholoog is of, hoe en wat een persoon met een beschadigd brein kan leren en of hij/zij op dezelfde wijze leert als een persoon met een gezond brein. Na een hersenletsel kunnen immers de cognitieve functies zijn aangedaan; dit worden ook wel de denkfuncties genoemd en daarmee komen we bij mijn uitgangsvraag: 'ik denk dus ik leer?'

In het onderzoek op het gebied van de neuropsychologische behandeling proberen we effectieve behandelingen te ontwikkelen en evalueren, waarbij telkens op een ander niveau wordt geleerd door de patiënt en diens naasten. Ik zal een aantal voorbeelden geven van ons eigen onderzoek aan de hand van het referentiekader van de ICF:

\section{Cognitieve functietraining}

Cognitieve functietraining is erop gericht om cognitieve stoornissen te verminderen. Het onderliggende idee is dat herstel van cognitieve functies wordt bevorderd door herhaalde oefening of training, zoals dat ook bij spieren het geval is ${ }^{14}$. Dit wordt ook wel de restoratieve benadering genoemd omdat er vanuit wordt gegaan dat de cognitieve functie kan herstellen. Er wordt dan veelal gebruikt gemaakt van spelletjes, al dan niet uitgevoerd op de computer; daarbij wordt ervan 
uitgegaan dat het uitvoeren van die taken kan leiden tot een verbetering van de onderliggende cognitieve functie. Een voorbeeld daarvan zou zijn het spelen van memory om het geheugen te trainen. Deze vorm van cognitieve revalidatie wordt veel toegepast en is vooral populair in de Verenigde Staten, maar leidt helaas niet tot het gewenste resultaat op het niveau van het dagelijks leven, omdat de effecten van dergelijke toepassingen slecht generaliseren ${ }^{15}$. Daarmee bedoel ik dat de prestaties op de getrainde taken verbeteren, maar dat deze effecten geen invloed hebben op de prestaties op andere taken. Anders gezegd: het spelen van memory zal er niet toe leiden dat een patiënt minder moeite heeft met het onthouden van het boodschappenlijstje voor de supermarkt. Ook zal het trainen van reactietijden bij een computerspelletje er niet toe leiden dat een patiënt veiliger zal handelen in het verkeer omdat hij of zij sneller kan reageren. Dergelijke resultaten zien we niet alleen als we cognitieve trainingen aanbieden aan patiënten met hersenletsel, maar ook als we dergelijke trainingen aanbieden aan ouderen om cognitieve achteruitgang te verminderen ${ }^{16}$.

Ik geef $u$ een voorbeeld van een behandeling op functieniveau. Een essentiële functie van het menselijk functioneren is het niveau van bewustzijn. $\mathrm{Na}$ een ernstig hersenletsel kan het niveau van bewustzijn ernstig zijn aangedaan waardoor de patiënt in een zeer laagbewuste toestand kan verkeren. Een bekend voorbeeld hiervan is het skiongeval van prins Johan Friso dat eerder dit jaar plaatsvond. Bij de berichtgeving rondom dit tragische ongeval werd aangegeven dat er nog geen effectieve behandelprogramma's bestaan om het herstel van het bewustzijn van volwassen patiënten te bevorderen. Het promotieonderzoek van Henk Eilander betrof de evaluatie van het behandelprogramma Vroege Intensieve Neurorevalidatie (VIN), dat in revalidatiecentrum Leijpark (Tilburg) is ontwikkeld voor kinderen en jongeren tot 25 jaar in een vegetatieve of laagbewuste toestand ${ }^{17}$. Gedurende deze behandeling krijgt de patiënt op zeer gestructureerde wijze zintuiglijke en cognitieve prikkels toegediend om een steeds meer gerichte reactie uit te lokken. In Nederland worden kinderen en jongeren vanuit het gehele land naar dit programma verwezen en is in het kader van het onderzoek een groep kinderen en jongeren gevolgd gedurende hun revalidatie en soms tot vele jaren erna. Strikt genomen is er door ons niet onderzocht of dit programma effectief is, omdat er slechts één groep patiënten is gevolgd en het niet bekend is wat de toestand van deze mensen zou zijn geweest zonder deze behandeling of na aanbod van een alternatieve behandeling. 
Wel kunnen we kijken naar de herstelcurves van deze groep patiënten en het percentage patiënten met een verbeterd bewustzijnsniveau ten opzichte van groepen patiënten in andere landen die het VIN programma niet hebben gevolgd ${ }^{17}$. Uit ons onderzoek is gebleken dat tweederde deel van de VIN patiënten kon worden ontslagen naar een regulier revalidatieprogramma omdat hun bewustzijnstoestand sterk verbeterd was; dit percentage is hoger dan verwacht en dan was gevonden in eerdere studies. Een deel van de patiënten vertoonde echter helemaal geen verbetering. De herstelcurves laten zien dat er verschillende herstelpatronen kunnen worden onderscheiden, waarbij de snelheid van herstel in de eerste paar weken na het letsel bepalend zijn voor de uitkomst op de langere termijn. Verder onderzoek naar de effectiviteit van dergelijke behandelprogramma's is dringend gewenst, maar methodologisch gezien wel moeilijk uitvoerbaar.

Een andere vorm van behandeling op functieniveau betreft het gebruik van medicatie gericht op het verbeteren van cognitieve, emotionele of gedragsmatige functies. Het promotieonderzoek van psychiater Bert ter Mors zal zich de komende jaren hierop richten. Helaas is er nog weinig bekend over de effectiviteit van medicamenteuze behandeling na hersenletsel ${ }^{18}$ en is onderzoek op dit terrein dan ook wenselijk. Een voorbeeld van een onderzoek van een Australische onderzoeksgroep waarmee wij samenwerken, betreft de effectiviteit van methylfenidaat, ook wel bekend als Ritalin, om de aandachtsfuncties na hersenletsel te verbeteren ${ }^{19}$. In dit onderzoek is een groep patiënten die 2 weken Ritalin gebruikte, vergeleken met een groep patiënten die een placebo ontving. Het onderzoek liet zien dat de Ritalin-groep na de behandeling een aantal cognitieve taken sneller kon uitvoeren dan de controlegroep, terwijl dit niet ten koste ging van hun nauwkeurigheid. Als echter aan de fysiotherapeuten werd gevraagd om de aandachtsfuncties tijdens de therapie te scoren, bleek er geen verschil te zijn tussen de groepen; de Ritalin groep kon zich tijdens de therapie niet beter concentreren dan de controlegroep. Dit betekent dat het effect van de medicatie niet generaliseert naar het dagelijks leven, zoals ik ook al eerder aangaf bij de cognitieve trainingen.

\section{Training van activiteiten}

Een oplossing voor het gebrek aan effectiviteit op het niveau van het dagelijks leven is om de training aan te bieden op het niveau van de activiteiten zelf. De patiënt wordt dan een specifieke vaardigheid 
geleerd die hij of zij graag weer wil leren of nodig heeft om zelfstandig te kunnen functioneren. Dit wordt wel de compensatoire benadering genoemd omdat er niet naar wordt gestreefd om de functie zelf te herstellen, maar om te compenseren voor de verloren gegane functie. Zo kan een ergotherapeut een patiënt leren om met één hand veters te strikken als er maar één hand beschikbaar is. Het voordeel van een dergelijke aanpak is dat het resultaat van de training direct toepasbaar is in het dagelijks leven. Het nadeel is dat ook deze aanpak niet generaliseert naar andere taken en je alle benodigde vaardigheden apart zou moeten trainen. Dat nadeel is er niet als de patiënt in staat is om strategieën aan te leren ter compensatie van verloren gegane functies. Een strategie kan immers bij meerdere taken gebruikt worden als de patiënt voldoende inzicht heeft om die mogelijkheden te overzien. Een voorbeeld van een geheugenstrategie is het opschrijven van informatie die niet vergeten moet worden. Een boodschappenlijstje in de supermarkt is daar een bekend voorbeeld van. En zo gebruik ik vandaag een diapresentatie ter ondersteuning van mijn verhaal. leke Winkens heeft in haar promotieonderzoek onderzocht of het mogelijk is om patiënten strategieën aan te leren ter compensatie van hun mentale traagheid ${ }^{20}$. Zoals ik in de inleiding al aangaf is een verminderde snelheid van informatieverwerking een veel gehoorde klacht na hersenletsel. Als je minder snel kunt denken, heb je daar last van in allerlei dagelijkse situaties waarin tijd een rol speelt. $U$ kunt daarbij denken aan deelname aan het verkeer of het koken van een maaltijd met meerdere gangen en pannen op het vuur, maar ook het volgen van een gesprek of luisteren naar een oratie kan lastig worden omdat het spreektempo misschien te snel gaat. De patiënt ervaart tijdsdruk waardoor activiteiten in het dagelijks leven dreigen mis te lopen, maar waardoor ook irritaties, frustraties en zelfs somberheid kunnen ontstaan. In het promotieonderzoek van leke Winkens ${ }^{20}$ hebben we daarom een training ontwikkeld en geëvalueerd waarin patiënten leren omgaan met tijdsdruk. Zoals uit mijn betoog al is gebleken, is het mogelijk om met cognitieve training en met medicatie de snelheid van informatieverwerking van het brein te verhogen, maar blijven de behandelresultaten helaas beperkt tot verbetering op taken gerelateerd aan de getrainde taken. Om ook effecten in het dagelijks functioneren te kunnen bewerkstelligen, hebben wij ervoor gekozen om niet de mentale snelheid zelf te verhogen, maar om de patiënt strategieën aan te leren om beter om te kunnen gaan met situaties waarin tijdsdruk ontstaat. Aangezien dergelijke situaties in ieders leven optreden, ook zonder 
hersenletsel, kan ik u aanraden nu goed op te letten. We hebben de patiënten twee soorten strategieën aangeleerd: preventieve strategieën om tijdsdruk te voorkomen en hanterende strategieën als tijdsdruk toch optreedt. Ik neem een praktische taak als autorijden in een vreemde, maar grote stad als voorbeeld. Het verkeer kan heel hectisch zijn en in een vreemde omgeving kan het zo zijn dat de patiënt niet alles meer overziet, fouten gaat maken en in paniek raakt. We vragen de patiënt om een gedetailleerde beschrijving te maken van het bezoek aan de stad. Vervolgens vragen we om, samen met de behandelaar, een analyse te maken van elementen van het bezoek die mogelijk tot problemen kunnen leiden. Er kan zich op de route bijvoorbeeld een ingewikkeld kruispunt bevinden dat vooral tijdens de spitsuren erg druk is. Een preventieve strategie zou dan kunnen zijn om een alternatieve route te kiezen of het bezoek niet tijdens de drukke uren af te leggen. Mocht het niet mogelijk zijn om deze preventieve maatregelen adequaat toe te passen, kunnen ook hanterende strategieën worden gebruikt. In dit voorbeeld zou dat kunnen betekenen dat een medepassagier bijvoorbeeld even het stuur overneemt of dat de patiënt eerst langs de kant van de weg parkeert om de verkeerssituatie te overzien alvorens er naar toe te rijden. Als de patiënt eenmaal heeft geleerd hoe de analyse van tijdsdruk in dagelijkse activiteiten in zijn werk gaat, kan hij of zij deze vervolgens zelfstandig ook in andere situaties toepassen. Uit een onderzoek waarin we een groep patiënten die de training 'Omgaan met tijdsdruk' hadden ontvangen, vergeleken met een groep patiënten die de gebruikelijke zorg ontvingen, bleek dat de nieuwe behandeling succesvol was en patiënten sneller konden handelen zonder dat dit ten koste ging van de nauwkeurigheid. Het aanleren van dergelijke compensatoire strategieën is op meerdere cognitieve domeinen, zoals geheugen, planning en waarneming, een effectieve vorm van behandeling gebleken ${ }^{21-25}$.

\section{Verbeterde maatschappelijke participatie}

Het is ook mogelijk en effectief gebleken om geïntegreerde neuropsychologische behandelprogramma's aan te bieden gericht op de maatschappelijke re-integratie van patiënten met hersenletsel in het chronische stadium. Een voorbeeld daarvan is het programma Brain integration dat in revalidatiecentrum Groot Klimmendaal (Arnhem) is ontwikkeld en bovendien op effectiviteit is onderzocht in het promotieonderzoek van Gert Geurtsen ${ }^{26}$. Tijdens de Brain Integration behandeling wordt patiënten geleerd een evenwicht te vinden in hun dagelijkse activiteiten met betrekking tot huishoudelijke taken, werk, vrije 
tijd en sociale relaties, rekening houdend met individuele capaciteiten en beperkingen. Uit het effectonderzoek bleek dat voorafgaand aan het programma $25 \%$ van de patiënten zelfstandig kon wonen, terwijl dit een jaar na afloop van het programma $66 \%$ betrof. Voorafgaand aan de behandeling had $18 \%$ van de patiënten betaald werk; een jaar na afloop van de behandeling was dit percentage opgelopen tot $54 \%$. Uit zeer recent onderzoek blijkt dat deze percentages 3 jaar later stabiel hoog zijn gebleven ${ }^{27}$. Dit zijn belangrijke resultaten vanuit het perspectief van de kosten van de gezondheidszorg. Programma's zoals Brain Integration zijn duur, maar uit een kostenanalyse die wij hebben uitgevoerd, is gebleken dat de kosten van het programma binnen 8 jaar kunnen worden terugverdiend en dat de baten zich uitstrekken over een periode van bijna 30 jaar omdat deze relatief jonge patiënten nog een lang werkzaam leven voor zich hebben ${ }^{28}$. Dergelijke economische evaluaties vormen een essentiële ondersteuning voor de keuzes in de gezondheidszorg.

Ik heb u nu voorbeelden van onderzoek gegeven op het niveau van de mentale functies, activiteiten en participatie. Deze onderzoeksprojecten laten zien hoe de neuropsycholoog effectieve behandelingen kan aanbieden op de verschillende niveaus van het ICF model, maar zoals al bleek uit het verhaal van de voorbeeldpatiënt is het ook van belang om de invloed van de persoonlijke en omgevingsfactoren te optimaliseren.

\section{Invloed van persoonlijke factoren}

Persoonlijke factoren kunnen een positieve invloed, maar ook een negatieve invloed hebben op het leven na een hersenletsel. Er zijn persoonlijke factoren die we met behandeling en begeleiding kunnen beïnvloeden, maar er zijn ook factoren waar we alleen maar rekening mee kunnen houden en niet kunnen beïnvloeden. Zo heeft een patiënt een bepaalde leeftijd op het moment dat het letsel optreedt en is een hogere leeftijd minder gunstig voor de prognose. Helaas behoort het verlagen van de leeftijd niet tot onze therapeutische mogelijkheden. Hetzelfde geldt voor het opleidingsniveau: hoe hoger de opleiding voorafgaand aan het letsel, des te beter de prognose, maar daar kunnen we helaas achteraf geen invloed meer op uitoefenen. Een aantal persoonlijke factoren zijn gelukkig wel vatbaar voor verandering en kunnen dan ook expliciete aandacht krijgen in de behandeling. In het promotieonderzoek van Gisela Wolters-Gregorio hebben we gekeken naar de invloed van de copingstijl van een patiënt op diens functioneren ${ }^{29}$. De copingstijl 
geeft aan hoe iemand omgaat met stressvolle situaties en daarin onderscheiden we verschillende stijlen die gunstig of ongunstig kunnen zijn voor het aanpassingsproces na hersenletsel. Grofweg kunnen er 2 soorten stijlen worden onderscheiden: actieve, probleem-gerichte copingstijlen en meer passieve, emotie-gerichte copingstijlen. De actieve 'coper' ziet in elk probleem een uitdaging zoals ook het geval was bij de voorbeeldpatiënt, terwijl de passieve 'coper' liever in een stil hoekje wacht to het probleem voorbij is. Uit ons onderzoek is gebleken dat patiënten met een meer actieve stijl een beter behandelresultaat laten zien en een hogere kwaliteit van leven rapporteren op de langere termijn. Er is in de literatuur nog discussie of copingstijlen een persoonlijkheidskenmerk zijn of dat ze een toestand representeren, maar als het laatste het geval is biedt dit mogelijkheden voor behandeling: als we een patiënt met een passieve stijl meer probleemgerichte strategieën kunnen aanleren, is de kans op een beter eindresultaat groter.

\section{Omgevingsfactoren}

Ook de partner van de patiënt heeft een copingstijl die in meer of mindere mate van invloed is op zijn of haar eigen functioneren en kwaliteit van leven. Uit het onderzoek van Gisela Wolters-Gregorio is gebleken dat het stimuleren van een meer actieve copingstijl bij de naastbetrokkenen een speerpunt voor revalidatiebehandeling zou kunnen zijn ${ }^{30}$. En darmee ben ik aangekomen bij een voorbeeld van onderzoek op het laatste niveau van de ICF, de omgevingsfactoren. Ook in dit geval zijn er factoren die beïnvloedbaar zijn en factoren waar alleen maar rekening mee gehouden kan worden. $U$ kunt zich voorstellen dat het krijgen van een beroerte in een westers, ontwikkeld en rijk land als Nederland tot betere gezondheidsuitkomsten zal leiden dan wanneer de patiënt zich in een ontwikkelingsland bevindt.

Een belangrijke omgevingsfactor voor de patiënt met hersenletsel zijn de mantelzorgers, die zowel praktische als emotionele steun kunnen bieden. Uit het promotieonderzoek van Anne Visser-Meily ${ }^{12}$ bleek dat veel partners in de loop van de tijd overbelast raken en somber worden. Dit bleek niet alleen gerelateerd te zijn aan de ernst van het letsel van hun partner, maar vooral ook aan hun eigen kenmerken en eigenschappen. Zo kunt u zich voorstellen dat de gezondheidstoestand van de partner zelf van invloed is op diens draagkracht in de zorg voor een ander. Uit een inventarisatie van werkzame interventies voor partners van patiënten met een beroerte bleek dat het actief stimuleren van het zoeken naar sociale steun en het aanleren van probleemoplossende vaardigheden tot 
betere gezondheidsuitkomsten en een hogere kwaliteit van leven van de partners kan leiden ${ }^{31.32}$. In Nederland, maar ook in andere landen wordt het geven van mantelzorg gestimuleerd en wordt ervan uitgegaan dat het vervangen van formele door informele zorg tot bezuiniging in de kosten van de zorg zou kunnen lieden. Uit ons onderzoek blijkt echter dat het van groot belang is om de naaste familie niet alleen als partners in de zorg voor de patiënt te zien, maar vooral ook te luisteren naar de hulpvraag van de naastbetrokkenen zelf. Familiegerichte zorg lijkt op de korte termijn misschien duurder, maar biedt op de langere termijn betere resultaten voor alle betrokken partijen.

Deze voorbeelden laten zien dat wij ons in ons onderzoek richten op alle gebieden van het menselijk functioneren. Bovendien laten deze voorbeelden van onderzoek op het gebied van de neuropsychologische interventies zien, dat er veel kennis is opgebouwd en dat er al vele effectieve behandelingen beschikbaar zijn. Er is zogezegd een gedegen 'evidence base' voor de klinische praktijk verkregen. Uit een serie recente systematische reviews op het gebied van de cognitieve revalidatie ${ }^{21-25}$ is gebleken dat de effectiviteit van behandeling in redelijke mate is vastgesteld, waarbij de grootste effecten zijn bereikt met het aanleren van compensatoire strategieën voor verminderde cognitieve functies. Vanzelfsprekend blijven er ook vele onderzoeksvragen over en kan ikmaar ook mijn collega wetenschappers op dit gebied - de vraag of, hoe en wat een patiënt met hersenletsel kan leren, nog steeds niet volledig beantwoorden.

\section{Onderzoeksagenda}

En dat brengt mij bij de onderzoeksagenda voor de komende jaren. De volgende 3 onderzoekslijnen staan centraal bij de invulling van mijn leeropdracht:

1. De eerste lijn betreft de ontwikkeling en evaluatie van meetinstrumenten om enerzijds de indicatiestelling voor neuropsychologische behandeling te kunnen aanscherpen en anderzijds de effecten van behandeling te kunnen vaststellen. Klassieke neuropsychologische testen zijn niet geschikt om op deze domeinen te kunnen meten, omdat deze instrumenten tot doel hebben om (cognitieve) stoornissen in kaart te brengen, terwijl de doelstelling van behandeling veel meer is gelegen op het niveau 
van onafhankelijk functioneren in het dagelijks leven en optimale participatie in de maatschappij. Daartoe dienen andere instrumenten te worden ontwikkeld die naast de toets op validiteit, betrouwbaarheid en responsiviteit (gevoeligheid voor verandering), vooral ook worden getoetst op 'ecologische validiteit'. Ecologische validiteit verwijst naar de mate waarin testresultaten verkregen onder gestandaardiseerde en gecontroleerde omstandigheden gegeneraliseerd kunnen worden naar een natuurlijke omgeving zoals het dagelijks leven van een patiënt. Een voorbeeld van een nieuw instrument dat momenteel door onze groep wordt ontwikkeld is een instrument om de mate van inzicht in eigen functioneren na een hersenletsel te meten. Veel patiënten hebben verminderd inzicht in hun eigen functioneren en $u$ kunt zich voorstellen dat dat tot onveilige situaties kan leiden, maar ook tot een slechte motivatie voor behandeling. Het is dus van belang om dit te kunnen meten en te kunnen vaststellen of verminderd inzicht van invloed is op de behandeling en of het in de loop van de tijd verandert.

2. De tweede onderzoekslijn betreft de evaluatie van de (kosten) effectiviteit van neuropsychologische behandeling en revalidatie. Voor de cognitieve revalidatie is de effectiviteit van behandeling in redelijke mate vastgesteld, zoals ik al eerder aangaf. Een belangrijke volgende stap is te onderzoeken wat werkt bij wie. Bovendien kunnen bewezen werkzame interventies worden onderzocht op effectiviteit in nieuwe doelgroepen voor behandeling. Een voorbeeld daarvan is de toepassing van bestaande effectieve interventies bij de oudere verpleeghuispopulatie of de jongere oncologiepopulatie. Daarnaast is de uitdaging gelegen in het vergroten van de evidencebase op het gebied van emotionele en gedragsmatige gevolgen van hersenletsel. Zo is er bijvoorbeeld nog geen effectieve behandeling voor agressie na hersenletsel. Een nieuwe richting is onderzoek naar de neurobiologische basis van gedragsverandering na neuropsychologische behandeling: wat gebeurt er precies in het brein als gevolg van neuropsychologische behandeling?

3. De derde lijn betreft onderzoek naar factoren van invloed op het succes van behandeling. Het is vaak niet duidelijk waarom eenzelfde cognitieve training grote individuele verschillen in effectiviteit laat zien. Veelal is dit fenomeen toe te schrijven aan persoonlijke en omgevingsfactoren die in meer of mindere mate van invloed zijn 
op het functioneren van een persoon. Het is van belang om te identificeren welke factoren dit zijn en in hoeverre deze factoren beïnvloedbaar zijn met behandeling en begeleiding. Zo is bekend dat de persoonlijke copingstijl (hoe gaat de persoon om met problemen?) een rol speelt zoals ik al eerder aangaf bij de voorbeelden van onderzoek; deze factoren worden momenteel in lopend onderzoek verkend. Een onderzoekslijn die verder zal worden uitgebreid is de invloed van het individuele leervermogen op de uitkomst van behandeling; daarin kunnen factoren als werkgeheugen en planning een grote rol spelen zonder dat deze zijn aangedaan door het letsel. Voor deze lijn zal ook veel voorwerk bij gezonde proefpersonen moeten worden verricht omdat er nog weinig bekend is over het leervermogen na hersenletsel, wat natuurlijk ook al duidelijk was uit de door mij gestelde centrale vraag 'ik denk dus ik leer?'

Deze onderzoekslijnen hoop ik de komende jaren samen met mijn onderzoeksgroep te kunnen uitvoeren. Het onderzoek zal succesvol zijn als de resultaten enerzijds kunnen worden vertaald in de gewenste wetenschappelijke doelstellingen zoals publicaties in internationale gerenommeerde tijdschriften, maar anderzijds is het voor mij als toegepast wetenschapper ook van essentieel belang dat de zorg voor patiënten met hersenletsel daadwerkelijk verbetert als gevolg van ons onderzoek. We kunnen wetenschappelijk onderzoek richten op de patiënt van nu of de patiënt van morgen, maar dan weten we nog niet precies wanneer morgen is. Mijn onderzoek richt zich vooral op de patiënt van nu en daarom staat de implementatie van onderzoeksresultaten in de dagelijkse klinische praktijk dan ook hoog op mijn prioriteitenlijst.

\section{Horizon}

Naast wetenschappelijke en gezondheidszorgproducten als concrete resultaten van mijn onderzoek, zie ik bovendien nog een aantal andere ontwikkelingen aan de horizon die ik hier graag met $u$ zou willen delen.

Er wordt de laatste jaren veel onderzoek naar de werking van de hersenen gedaan en er worden grote sprongen vooruit gemaakt. Het is nog niet zo lang gelden dat we het brein alleen konden bestuderen nadat iemand was overleden; daarna werd het mogelijk om de structuur van het brein in kaart te brengen en sinds enkele jaren is het mogelijk om ook het brein te bestuderen terwijl er allerlei taken worden uitgevoerd, zoals bij de toepassing van functionele MRI. Dergelijk onderzoek is heel 
populair bij subsidieverstrekkers en bij het grote publiek. Kijkt u maar eens in de boekwinkel hoeveel boeken er de laatste tijd over het brein verschijnen. Voor de patiënt die moet leren leven met de veelal blijvende gevolgen van hersenletsel, de patiënt van nu, heeft dit onderzoek naar het functioneren van de hersenen helaas nog maar heel weinig concrete oplossingen aangedragen. Aan de horizon zie ik dan ook een nauwere samenwerking tussen de neurowetenschappers die op meer fundamenteel niveau de werking van ons brein onderzoeken en de toegepaste wetenschappers die patiëntgebonden onderzoek uitvoeren in de dagelijkse klinische praktijk. Ik zal mij ervoor inzetten dat niet alleen de hersenen óf het gedrag worden bestudeerd, maar de relatie tussen hersenen én gedrag in de context van de patiënt. Binnen mijn eigen vakgebied zie ik aan de horizon doorbraken met betrekking tot de neurobiologische basis van behandeling en de effecten daarvan; het zou een belangrijke stap voorwaarts zijn als we effectieve cognitieve trainingen aan kunnen bieden waarbij de functie herstelt én de patiënt beter functioneert in het dagelijks leven.

In de gezondheidzorg worden veel aandacht en middelen besteed aan de acute medische zorg. De kansen om een ernstig hersenletsel te overleven worden steeds groter, maar zoals ik aan het begin van deze rede al aangaf, blijven er daardoor meer mensen leven met de veelal blijvende gevolgen van het letsel. Aan de horizon zie ik meer erkenning en herkenning van de lange termijn gevolgen van hersenletsel en zie ik een centrale positie voor de neuropsycholoog voor de verbetering van de zorg op dit gebied. Voor degenen die daar meer over willen weten, verwijs ik graag naar de oratie van prof.dr. Rudolf Ponds op 2 november aanstaande.

Een van de mogelijke succesfactoren van effectieve cognitieve trainingen zou wel eens de intensiteit van behandeling kunnen zijn. Eén bekend spreekwoord zegt het al: 'oefening baart kunst' en zowel in de muziek als de sportwereld is bekend dat het aantal uren oefening een bepalende factor is voor virtuositeit. In de media wordt gesproken van het 10.000 uren criterium om expert te worden. Om de intensiteit van behandeling te kunnen vergroten, is voldoende capaciteit aan neuropsychologen noodzakelijk. Daarnaast zal de neuropsycholoog qua positie een centrale rol moeten innemen in het behandelteam en de regie van de zorg naar zich toe moeten trekken. Aan de horizon zie ik een accentverschuiving in ons vakgebied van diagnostiek naar behandeling. 
De academische wereld is een harde en competitieve wereld en helaas dragen de bezuinigingen op academische middelen in ons land niet bij aan een verbetering van deze situatie. Academische successen worden vooral bepaald aan de hand van de wetenschappelijke impact van ons werk, uitgedrukt in allerlei lijstjes en indexen waarop je je blind kunt staren zonder te weten wat er precies mee bedoeld wordt. Aan de horizon zie ik een academisch beoordelingssysteem waarbij de maatschappelijke impact van onderzoeksresultaten eveneens wordt gehonoreerd en een respectabele plaats inneemt naast de wetenschappelijke indicatoren van succes. Het is daarom goed om te constateren dat kwaliteit van leven juist één van de drie speerpunten is geworden van deze universiteit.

De wijze waarop ik met mijn collega-onderzoekers tegenwoordig moet strijden om de schaarse middelen toebedeeld te krijgen, leidt er soms toe dat de samenwerking op de werkvloer steeds meer gelijkenis vertoont met het optreden van het Nederlands elftal tijdens het laatste EK: er was een groep individuele experts aan het werk die elk op zich met hun inzet en prestaties de beker verdienden, maar door een gebrek aan samenwerking op het niveau van het team was het spel voorbij na de eerste ronde. Aan de horizon zie ik wetenschappers van verschillende disciplines en academische centra nauwer met elkaar samenwerken omdat ik ervan overtuigd ben dat dat de enige juiste werkwijze is om grenzen te kunnen verleggen en doorbraken te realiseren in wetenschappelijk onderzoek. 


\section{Tot slot}

Ik hoop dat ik $u$ tijdens deze rede veel heb kunnen leren, maar vooral ook stof tot nadenken heb gegeven om de vraag 'ik denk dus ik leer?' vanuit het perspectief van mijn vakgebied te bekijken.

Dames en heren, ik ben aan het eind gekomen van het inhoudelijke deel van mijn oratie. Vandaag mag wel een mijlpaal in mijn leven worden genoemd. Mijlpalen moet je vieren en dat doe ik dan ook uitbundig. Ik ben blij dat $u$ erbij bent om dat samen met mij te doen.

Het vieren van mijlpalen doe je niet alleen, maar hoogleraar worden lukt ook niet zonder de inbreng van anderen. De Mont Ventoux opfietsen heb ik weliswaar zelf gedaan, maar niet zonder de stimulerende woorden van Peter de avond ervoor: 'we gaan gewoon fietsen en we stoppen pas als we boven zijn'. Zonder de stimulerende factoren in mijn omgeving had ik hier vandaag niet gestaan om het ambt van hoorleraar te aanvaarden. $U$ had natuurlijk al begrepen dat ik zelf de voorbeeldpatiënt ben die eerder in deze rede is gepresenteerd en dat de omgevingsfactoren een belangrijke rol spelen in mijn leven. Tot slot wil ik daarom graag nog een aantal woorden van dank uitspreken.

Allereerst wil ik het College van Bestuur van de UM, de Raad van Bestuur van het MUMC+, de beide decanen en faculteitsbesturen van de FHML en FPN bedanken voor het instellen van deze leerstoel en het in mij gestelde vertrouwen. In het bijzonder wil ik prof.dr. Martin Paul bedanken voor het instellen van het Top Talent Programma dat mij in korte tijd de mogelijkheden bood om hoogleraar te worden. Het is stimulerend dat de tweede lichting van dit programma alleen uit vrouwen bestaat; het is jammer dat dat blijkbaar nodig is om het percentage vrouwelijke hoogleraren aan deze universiteit te vergroten. Heren bestuurders, aan u zou ik daarom willen zeggen: denk eens vaker aan een vrouwelijke collega bij het invullen van een belangrijke functie. Ik weet niet hoe $u$ erover denkt, maar Duitsland vaart er wel bij. Dames onderzoekers, aan u zou ik willen zeggen: er is geen enkele reden om niet door te groeien tot hoogleraar. Ik ben erin geslaagd en help u graag dezelfde weg te gaan.

Aan het begin van mijn wetenschappelijke carrière hebben twee voor mij belangrijke mensen gestaan die later mijn beide promotoren werden: prof.dr. Joost Dekker en prof.dr. Betto Deelman. Jullie hebben mij het enthousiasme en de nodige tools gegeven om mijn weg in onderzoeksland succesvol te kunnen bewandelen. En hoewel er 
in Nederland en wereldwijd meerdere hoogleraren in de Klinische Neuropsychologie zijn benoemd, zijn er maar weinige die als aandachtsgebied neuropsychologische behandeling hebben. Jullie hebben samen met mij de eerste stappen op weg hiernaartoe gezet. Ik dank jullie hartelijk daarvoor.

Een bijzondere plek wordt ingenomen door de vele promovendi die hun onderzoek onder mijn begeleiding hebben afgerond of momenteel uitvoeren. Zonder al het mooie en waardevolle onderzoek dat jullie doen, was deze inaugurele rede een stuk minder interessant geweest. Fijn dat jullie er zijn!

Graag wil ik ook mijn huidige en voorgaande leidinggevenden bedanken voor de kansen en de ruimte die ze mij hebben gegeven om mijn eigen weg te gaan en mij bij te staan waar nodig. Veel steun en collegialiteit ontvang ik van de vele collega's die ik op de diverse werkplekken heb. Een aantal daarvan wil ik in het bijzonder noemen omdat zij mijn dagelijkse werk tot een prettige bezigheid maken: Rudolf, Frans, Martin, Marjolein en Petra. Rudolf, ik heb ervan genoten om dit traject samen gelijktijdig te doorlopen en ik kan je vast vertellen dat het erg leuk is om aan deze kant van de zaal te staan: veel succes op 2 november!

In het bijzonder wil ik vanaf deze plaats Anne Visser noemen. Anne, wij zijn de afgelopen jaren een zeer succesvol duo gebleken. Succesvol in vele opzichten: de ideeën die we samen genereren leiden veelal tot mooie en bruikbare producten. We zijn een voorbeeld van succesvolle samenwerking tussen academische centra en tussen disciplines. Ik zou er trots op zijn als meerdere collega's onze werkwijze kunnen volgen. Jij bent een van die collega's die zich op het grensvlak van collega's en vrienden bevindt. Naast werkgerelateerde zaken, delen we ook veel lief en leed samen en mag ik vaak gebruik maken van jullie gastvrije en gezellige logeeradres in Bunnik. Ik hoop dat we nog veel en vaak samen kunnen optrekken, waarbij het voor ons allebei soms beter zou zijn als we de balans tussen werken en wandelen wat beter verdelen.

Die balans wordt in mijn leven gelukkig bewaakt door de vele familieleden en vrienden met wie ik mijn vrije tijd doorbreng. Veel van jullie zijn vandaag hier aanwezig en ook al kan ik niet iedereen bij naam en toenaam noemen, ik vind het bijzonder fijn dat jullie er zijn, nu, maar ook samen met mij op weg naar deze belangrijke dag. 
Mijn ouders nemen in dit dankwoord een belangrijke plaats in. Lieve pappa, op het moment dat ik deze oratie voorbereid weet ik nog niet zeker of je vandaag aanwezig zult zijn, maar als je er bent, ben je zeker mijn eregast. Al vroeg in de ontwikkeling wordt de basis gelegd voor de toekomst en die basis blijkt in mijn geval tot een bijzondere wetenschappelijke functie te hebben geleid. Maar dat valt in het niets bij alle andere mogelijkheden, liefde en steun die ik altijd van jullie mag ontvangen en waarvan ik nog heel lang hoop te mogen genieten.

En last, but certainly not least: lieve Peter, je bent bovenal mijn partner, maar de afgelopen jaren ben je ook mijn coach geweest op weg naar deze mijlpaal. Als ik gefrustreerd of verdrietig thuiskom van een werkdag die niet helemaal is gelopen zoals ik had gewild, wil ik het liefste een troostende arm om me heen. Dat blijkt niet jouw stijl te zijn. Ik kan eerder rekenen op een nuchtere opmerking zoals 'ben je weer te hoog op de apenrots geklommen, dan wordt je er natuurlijk ook afgeduwd'. Of een opmerking in de lijn van Sigmund: 'het is maar werk, trut'. Op het moment zelf is dat niet waar ik op zit te wachten, maar dergelijke uitspraken zijn van onschatbare waarde in mijn ontwikkeling. Ik hoop er dan ook nog vele te mogen horen. Maar vooral hoop ik natuurlijk nog heel lang samen met jou intens te genieten van het leven.

Ik heb gezegd. 


\section{Referenties}

1 Deelman B, Eling P, de Haan E, van Zomeren E. Klinische Neuropsychologie. Amsterdam: Boom Uitgeverij, 2004.

2 Pam M. Het Ravijn. Autobiografie van de angst. Uitgeverij Prometheus, 2004.

3 Van Strien JW. Epidemiologie. In: JAM van dr Meulen, MMA Derix, CJJ Avezaat, Th Mulder en JW van Strien Niet aangeboren hersenetlsel bij volwassenen. Elsevier Gezondheidszorg, Maarssen 2003.

4 Vaartjes I, Reitsma JB, de Bruin A, et al. Nationwide incidence of first stroke and TIA in the Netherlands. European Journal of Neurology 2008;15: 1315-23.

5 Struijs JN. Modeling the future burden of stroke in the Netherlands: the impact of aging, hypertension and smoking. Stroke 2005, 36:1648-55.

6 Visser-Meily JMA, Van den Bos GAM, Kapelle LJ. Better acute treatments induce more investments in chronic care for stroke patients. International Journal of Stroke 2009; 4: 352-253.

7 Rasquin SM, Verhey FR, Lousberg R, Lodder J. Cognitive performance after first ever stroke related to progression of vascular brain damage: a 2 year follow up CT scan study. Journal of Neurology, Neurosurgery and Psychiatry 2005; 76(8): 1075-79.

8 Hochstenbach JB, Den Otter B, Mulder TW. Cognitive recovery after stroke: a 2 year follow up. Archives of Physical Medicine and Rehabilitation 2003; 84(10): 1495-1504.

9 Hochstenbach JB, Prigatano G, Mulder TW. Patients' and relatives' reports of disturbances 9 months after stroke: subjective changes in physical functioning, cognition, emotion, and behavior. Archives of Physical Medicine and Rehabilitation 2005; 86(8): 1587-1593.

10 Schepers VP, Visser-Meily AM, Ketelaar M, Lindeman E. Post-stroke fatigue: course and its relation to personal and stroke-related factors. Archives of Physical Medicine and Rehabilitation 2006; 87(2):184-8.

11 van de Port IG, Kwakkel G, Bruin M, Lindeman E. Determinants of depression in chronic stroke: a prospective cohort study. Disability and Rehabilitation 2007 ; 29(5): 353-8.

12 Visser-Meily JMA. Caregivers, partners in stroke rehabilitation. Dissertation. Universiteit Utrecht, 2005.

13 International Classification of Functioning, Disability and Health, WHO. [http://www.who.int/classifications/icf/en/]

14 Wilson BA. Cognitive Rehabilitation: how it is and how it might be. Journal of the International Neuropsychological Society 1997; 3(5): 487-496.

15 Spikman JM \& Fasotti L. Herstel en Behandeling. In: Kessels R, Eling P, Ponds R, Spikman J en van Zandvoort M: Klinische Neuropsychologie. Amsterdam: Boom Uitgeverij, 2012.

16 Reijnders J, van Heugten C, van Boxtel M. Cognitive interventions in healthy older adults and people with mild cognitive impairment; a systematic review. Ageing Research Review 2012; July 25 (epub ahead of print).

17 Eilander HJ. Children and young adults in a vegetative or minimally conscious state after brain injury. Dissertation. Universiteit Utrecht, 2008. 
18 CBO. Richtlijn behandeling van neuropsychiatrische gevolgen van niet-aangeboren hersenletsel. Utrecht: Kwaliteitsinstituut voor de Gezondheidszorg (CBO), 2007.

19 Wilmott C. \& Ponsford, J. Efficacy of methylphenidate in the rehabilitation of attention following traumatic brain injury: a randomized, cross-over, double blind, placebo-controlled inpatient trial. Journal of Neurology, Neurosurgery and Psychiatry 2009; 80: 552-557.

20 Winkens I, Heugten C van, Wade D, Habets E, Fasotti L. Efficacy of Time Pressure Management in stroke patients with slowed information processing: a randomized controlled trial. Archives of Physical Medicine and Rehabilitation 2009; 9o(10): 1672-9.

21 Cicerone KD et al. Evidence-based cognitive rehabilitation: recommendations for clinical practice. Archives of Physical Medicine and Rehabilitation 2000; 81: 1596-615.

22 Cicerone KD et al. Evidence-based cognitive rehabilitation: updated review of the literature from 1998 through 2002. Archives of Physical Medicine and Rehabilitation 2005; 86(8): 1681-92.

23 Cicerone KD et al. Evidence-based cognitive rehabilitation: updated review of the literature from 2003 through 2008. Archives of Physical Medicine and Rehabilitation 2011; 92: 519-30.

24 Rohling ML, Faust ME, Beverly B, Demaks G. Effectiveness of cognitive rehabilitation following acquired brain injury: a meta-analytic re-examination of Cicerone et al.'s (2000, 2005) systematic reviews. Neuropsychology 2009; 23(1): 20-39.

25 Van Heugten CM, Wolters Gregorio G, Wade DT. Evidence Based Cognitive Rehabilitation after acquired brain injury: systematic review of content of treatment. Neuropsychological Rehabilitation 2012; April 29 (epub ahead of print).

26 Geurtsen GJ, Heugten CM van, Martina JD, Meijer RM, Geurts AC. A prospective controlled study to evaluate a residential community reintegration for patients with chronic acquired brain injury. Archives of Physical Medicine and Rehabilitation 2011; 92: 696-704.

27 Geurtsen GJ, Heugten CM van, Martina JD, Rietveld T, Meijer RM, Geurts AC. Three year follow up results of a residential community reintegration for patients with chronic acquired brain injury. Archives of Physical Medicine and Rehabilitation 2012; 93: 908-11.

28 Van Heugten CM, Geurtsen GJ, Derksen E, Martina JD, Geurts ACH, Evers S. Cost-analysis of residential community reintegration for severe chronic brain injury: The Brain Integration Programme. Journal of Rehabilitation Medicine 2011; 32: 647-52.

29 Wolters G, Stapert S, Brands I, Heugten C van. Coping styles in relation to cognitive rehabilitation and quality of life after brain injury. Neuropsychological Rehabilitation 2010; 20(4): 587-600.

30 Wolters G, Stapert S, Brands I, Heugten CM van. Coping styles within the family system in the chronic phase following acquired brain injury: its relation to families' and patients' functioning. Journal of Rehabilitation Medicine 2011; 43: $190-6$. 
31 Visser-Meily JMA, Heugten CM van, Post MWM, Schepers VPM, Lindeman E. Intervention studies for caregivers of stroke patients: a critical review. Patient Education and Counseling 2005; vol 56(3), 257-67.

32 Van Heugten CM, Visser-Meily JMA, Post M, Lindeman E. Care for caregivers of stroke patients: evidence based guidelines. Journal of Rehabilitation Medicine 2006; 38: 153-8. 
